\title{
Legal Information Management
}

\section{Journal of the British and Irish Association of Law Librarians \\ Editor}

Laurence Eastham, The Coach House, Black Dog Hill, Studley, Calne,Wiltshire SNI I 9LT.Tel: 01249822400 Fax: 01249822522 E-mail Iseastham@aol.com

\section{Editorial Board}

Michelle Celik, B.A. A.L.A. Middleton Potts, London

David Gee, B.A., M.A., Dip.Lib., A.L.A., Institute of Advanced Legal Studies, London (Current Awareness Editor)

Jonathan Gordon-Till, B.Sc., MllnfSc, Aon Consulting, Harrow (Chair)

Kate Hodgson, B.Sc., Dip.Lib., A.L.A. CMS Cameron McKenna, London

Cathie Jackson, B.Sc. (Econ), M.Sc., PGCE (FE/HE), Cardiff University

Jean Lloyd, A.L.A., Manchester City Solicitors

Ruth McMahon, Matheson Ormsby Prentice, Dublin Caroline Mosley, B.A. Freelance Information Consultant, Birmingham

Dawn Patrick, B.Sc., Dip. (IS), London (Reviews Editor)

Phil Stant, B.A. Cert.Ed. (FE/HE), Faculty Librarian, Law and Social Sciences, University of Central England in Birmingham

Ceris Williams, B.A., M.Sc. A.L.A., Pinsent Curtis Biddle, Leeds
Jennie Yeomans, B.A., A.L.A., Freelance information consultant, Tunbridge Wells

Subscriptions

Sweet \& Maxwell Ltd., The Hatchery, Hall Bank Lane, Mytholmroyd, Hebden Bridge, W. Yorks, HX7 5HQ.

Back issues

William S. Hein \& Co Inc, I 285 Main Street, Buffalo, New York 14209, USA

The journal is published quarterly in March, June, September and December. It is indexed in Current Law Index, Legal Information Management Index, Legal Journals Index, Legal Resource Index, Library and Information Science Abstracts and Library Literature.

Current issues are available from Sweet \& Maxwell Ltd.,The Hatchery, Hall Bank Lane, Mytholmroyd, Hebden Bridge, W.Yorks, $\mathrm{H} \times 75 \mathrm{HQ}$ at cover cost plus postage and packing. Advertising rates are full page $£ 280$, half page $£ 175$ and inserts $₫ 375$.

Individual issues for $1997 / 2001$ cost $£ 15.00$.

Books for review should be sent to the Reviews Editor.

The closing dates for copy and notes on the preparation of manuscripts and the use of references are available from the Editor.

\section{British and Irish Association of Law Librarians}

\section{President}

Barbara Tearle

Chair

Valerie Stevenson, Faculty Information Consultant, Social

Sciences and Law, University of Aberdeen

Immediate Past Chair

John Furlong, Matheson Ormsby Prentice, 30 Herbert St,

Dublin 2

Vice Chair

John Miller, College of Europe, Bruges

Hon. Secretary

Catherine McArdle, Lincoln's Inn Library, London WC2A 3TH

Hon. Treasurer

Alden Bowers, Hammicks, 9 Broad St, Bristol BS I

$2 \mathrm{HL}$

\section{Elected Members}

Mark Field, Library Association, London

Hazel Hewison, Oxford Institute of Legal Practice, Oxford

Catherine Hewson, Andersons, London

Victoria Jannetta, Charles Russell, London

Judith Lowe, Eversheds, Newcastle Upon Tyne

\section{Administrator}

Susan Frost, B.A. (Hons), A.L.A., 26 Myton Crescent, Warwick CV34 6QA.Tel * Fax: 01926491717

The British and Irish Association of Law Librarians was founded in 1969 to promote the better administration and exploitation of law libraries and legal information units.

Full membership is open to persons and institutions engaged in the provision or exploitation of legal literature. Associate membership is open to individuals and institutions not so engaged, but who support the aims of the Association. Members are entitled to participate in Association activities, about which they are automatically notified.

Further information and membership application forms may be obtained from the Administrator at the above address.

Subscription rates $1 / 4 / 2001-31 / 3 / 2002$

Personal Members: $\quad £ 54$

Institutional Members: $\quad £ 90$

Retired and Unemployed Members: $\quad € 15$

Student Members: $\quad € 15$ 


\section{Does managing your information needs}

leave you in a

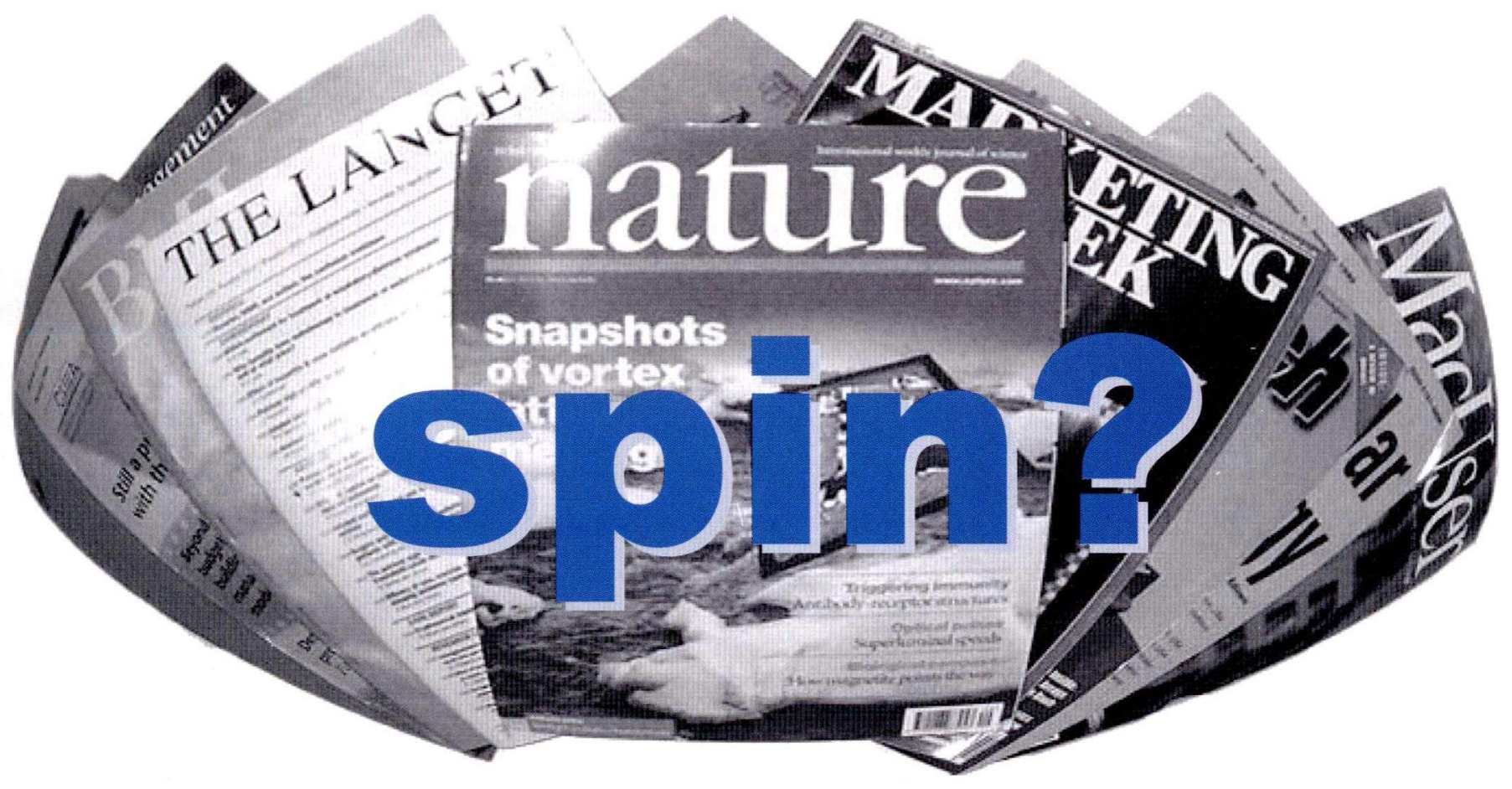

Let RoweCom help you with:

Periodical Subscriptions, Electronic Journals, Standing Orders, Books Budget Planning, Collection Analysis

RoweCom, Marlborough House, Sandy Lane West, Oxford, OX4 6LB tel. 0I865 332900 fax. 0I865 332990 email.info@rowecom.co.uk www.rowecom.co.uk 


\section{Intellectual Property and Technology Direct}

\section{Better by design!}

"...as we move to an information-based economy [IP law] will become as central as the law relating to land tenure was in the seventeenth century, or company law is today ..."

From Get ahead - get a security blanket by John Naughton, Observer, Sunday June 24, 2001

Butterworths online service, Intellectual Property and Technology Direct, will enable you to stay at the forefront of legislative changes and developments in EU and UK case law, providing the vital information you need to effectively advise your clients.

\section{How your life will be made easier:}

Up to date summaries focus attention on current IP and technology UK and EU cases and legislation, as well as legal and professional news.

Access an extensive archive of UK and EU case materials dating from 1936 and legislation at the touch of a button, thus avoiding laborious research.

Let the experts do the work for you - the service includes commentary in the form of Laddie, Prescott \& Vitoria: The Modern Law of Copyright and Designs (3rd edn, 2000) and Morcom, Roughton and Graham: The Modern Law of Trade Marks.

Leading practitioners discuss influential cases and legislative developments, guaranteeing access to current authoritative guidance.

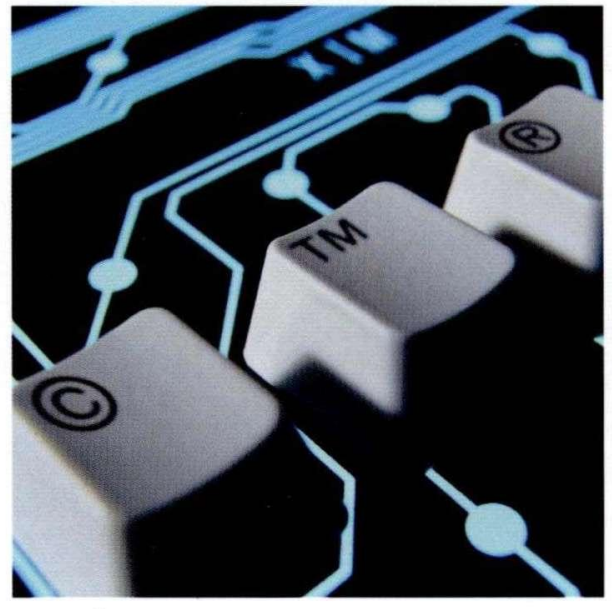

Prices for a single user start from £1,250 per annum

\section{Try this service FREE for a week! Simply call 08456081188 or register online at www.butterworths.com/freetrial}

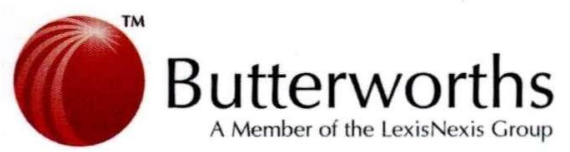

